\title{
Characterisation of macrogel composition from industrial natural rubber samples: Influence of proteins on the macrogel crosslink density
}

\author{
S. Rolere ${ }^{1}$, C. Bottier ${ }^{2}$, L. Vaysse $^{2}$, J. Sainte-Beuve ${ }^{1}$, F. Bonfils ${ }^{1 *}$ \\ ${ }^{1}$ CIRAD, UMR IATE, F-34060 Montpellier, France \\ ${ }^{2}$ CIRAD, UMR IATE, Kasetsart University, Bangkok, Thailand
}

Received 13 October 2015; accepted in revised form 7 December 2015

\begin{abstract}
The insoluble (macrogel) and soluble fractions of 11 commercial natural rubber (NR) samples (Technically specified rubber) were separated. Nitrogen titrations and lipid extractions enabled a quantitative assessment of the proteins and extractable lipids in each fraction. Swelling was measured in tetrahydrofuran in order to evaluate the crosslink density $\left(M_{\mathrm{c}}^{-1}\right)$ of each macrogel. While the soluble fraction had a high lipid concentration, the majority of non-isoprene compounds of the macrogel were found to be proteins, which accounted for 4.6 to $50.8 \%$ (w/w) of the macrogel. Indeed, the macrogels contained less than $0.5 \%(\mathrm{w} / \mathrm{w})$ extractable lipids. However, our results showed that the soluble fraction contained large quantities of proteins (16-66\% of the nitrogen content of the raw NR sample), probably structuring microaggregates. An exponential correlation $\left(R^{2}>0.96\right)$ was found between the crosslink density and the protein concentration of macrogel, suggesting that proteins are involved in the majority of crosslinks in macrogel.
\end{abstract}

Keywords: polymer gels, natural rubber, macrogel, proteins, crosslink density

\section{Introduction}

Natural rubber (NR) is made from the latex of Hevea brasiliensis, and accounts for $42 \%$ of global elastomer consumption [1]. Most of global NR production ( $70 \%$ of 12.1 million tons) is used by the tyre industry. Depending on the applications, several commercial grades can be used including technically specified rubbers (TSR, $>60 \%$ of global production), ribbed-smoked sheets (RSS, $\sim 20 \%$ ) and concentrated latex $(\sim 12 \%)$. The green side of this biopolymer is disadvantaged by the variability (or non-consistency) of its properties, which generates losses of materials and energy during the various stages of industrial processes [2]. In this article, our main objective was to gain a better understanding of variability in the composition and structure of macrogel fractions from very diverse industrial samples.
NR is composed of about $94 \%(\mathrm{w} / \mathrm{w})$ cis-1,4-polyisoprene $[3,4]$ and displays some outstanding mechanical properties, compared to synthetic rubbers $[2$, 5]. Its exceptional properties are attributed to the stereoregularity of the polyisoprene chain (high cis1,4 content), high polyisoprene molar masses [6-8], but also to the presence of a gel phase $[9,10]$. This gel phase is composed of an insoluble fraction called 'macrogel' [11, 12], and of microaggregates dispersed in the soluble fraction, called 'microgel' [13, 14] (Figure 1). Some non-isoprene compounds of NR, such as lipids $(1.5-4 \% \mathrm{w} / \mathrm{w})$ [4, 15-17], proteins $(1-3.5 \% \mathrm{w} / \mathrm{w})[4,17-19]$, and minerals $(0.2 \%$ $\mathrm{w} / \mathrm{w})[4,20]$, are assumed to be responsible for the existence of this gel phase. For example, macrogel can be eliminated by transesterification or deproteinization of NR. Consequently, Tanaka and cowork-

\footnotetext{
${ }^{*}$ Corresponding author, e-mail: frederic.bonfils@,cirad.fr (C) BME-PT
} 
ers $[21,22]$ suggested the presence of esterified compounds, such as phospholipids, covalently bonded to the $\alpha$-terminal group of the macromolecule. The authors also suggested physical interactions between proteins and the $\omega$-terminal group of the polymer [21]. Nevertheless, the role of each nonisoprene compound, as well as the nature of the terminal groups of the cis-1,4-polyisoprene chains of $\mathrm{NR}$, is still unclear.

The amounts of gel present in NR samples are usually quantified after dissolution in organic solvents, such as toluene or tetrahydrofuran [23-25] (Figure 1). After dissolution, macrogel is eliminated by centrifugation. Filtration of the soluble fraction can then be used to quantify the microgel either directly by weighing the recovered microgel [25], or indirectly using SEC-MALS (size exclusion chromatography, multiple angle light scattering) analyses [12, 26]. Several studies showed that proteins are concentrated in the macrogel of NR [27-29]. Proteins are known to be insoluble in the organic solvents used for NR dissolution. Consequently, proteins not involved in the structure of macrogel could also precipitate with the macrogel during the centrifugation step (Figure 1). Thus, the high protein contents of macrogel cannot be directly used to study the role of those non-isoprene compounds in macrogel structuring. Indeed, earlier work showed that washing macrogel with water, helped to eliminate nonstructuring minerals and proteins [30].

In order to gain a better understanding of variability in the composition and structure of macrogel fractions from very diverse industrial samples, macrogels extracted from 11 different NR industrial samples were characterized. The protein content and

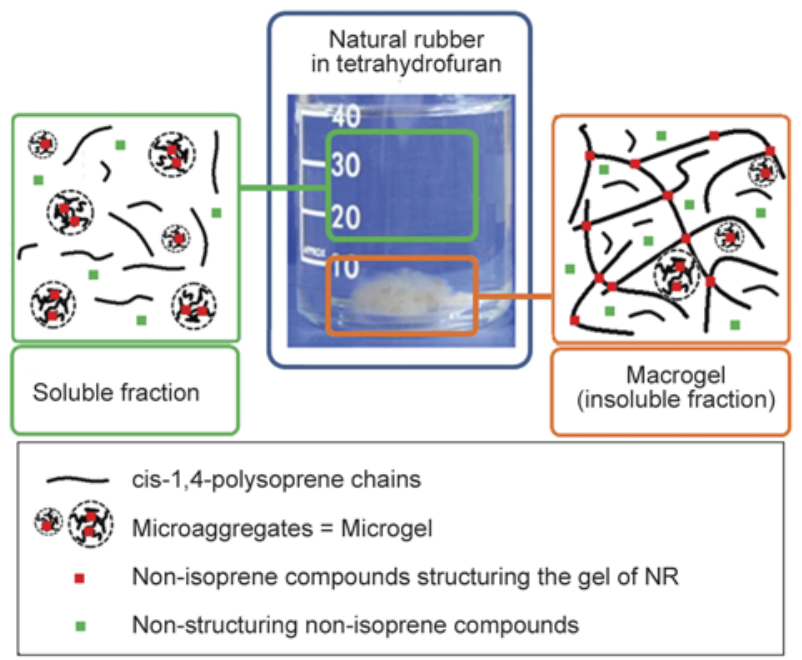

Figure 1. Diagram of the insoluble (macrogel) and soluble fractions present in a solution of natural rubber dissolved at $0.1 \%(\mathrm{w} / \mathrm{v})$ in tetrahydrofuran

lipid composition of the respective washed macrogels and soluble fractions were investigated, using chemical analyses and FT-IR (Fourier transform infrared) spectroscopy. The crosslink density of each macrogel sample was also estimated by swelling measurements. Lastly, the effect of non-isoprene compound concentrations on macrogel structure was investigated.

\section{Experimental section \\ 2.1. Materials}

Eleven commercial NR samples of TSR10, TSR10CV and TSR3CV grades were produced in Côte d'Ivoire, Thailand and Vietnam, under controlled conditions (Table 1). TSR (Technically specified rubber) grades account for more than $60 \%$ of global NR production. Usually, commercial NRs are made with a mixture of fresh latex (TSR3CV grade), or coagula

Table 1. Characteristics of the 11 natural rubber samples

\begin{tabular}{|c|l|l|l|c|c|}
\hline Sample & \multicolumn{1}{|c|}{ Grade } & \multicolumn{1}{|c|}{ Clone } & \multicolumn{1}{|c|}{ Country } & $\begin{array}{c}\text { Age [months] of sample before } \\
\text { analysis }^{*}\end{array}$ & $\begin{array}{c}\text { Macrogel } \\
{\left[\begin{array}{l}\text { w/w] } \\
\text { w }\end{array}\right.}\end{array}$ \\
\hline A & TSR10 & GT1 & Côte d'Ivoire & 26 & 14.0 \\
\hline B & TSR10 & GT1 & Côte d'Ivoire & 22 & 15.4 \\
\hline C & TSR10 & RRIM600 & Thailand & 14 & 25.7 \\
\hline D & TSR10 & RRIM600 & Thailand & 14 & 5.2 \\
\hline E & TSR10 & GT1 & Côte d'Ivoire & 26 & 4.7 \\
\hline F & TSR10CV & GT1 & Côte d'Ivoire & 30 & 2.1 \\
\hline G & TSR10CV & GT1 & Côte d'Ivoire & 30 & 1.3 \\
\hline H & TSR10 & PB235 & Côte d'Ivoire & 30 & 2.8 \\
\hline I & TSR10 & GT1 & Côte d'Ivoire & 32 & 3.6 \\
\hline J & TSR3CV & GT1 & Vietnam & 32 & 1.6 \\
\hline K & TSR3CV & GT1 & Vietnam & 30 \\
\hline
\end{tabular}

${ }^{*}$ To work on stable sample, as several papers showed storage hardening reachs a plateau after about 10-14 months, most of the samples were used after at least 14 months of storage. 


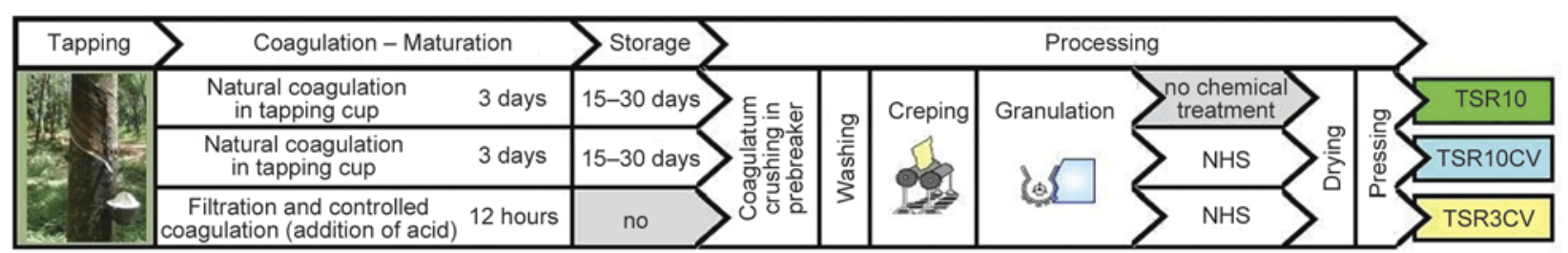

Figure 2. Diagram of the processing conditions used to prepare TSR10, TSR10CV and TSR3CV grades (reprinted from [17], by courtesy of Elsevier)

(TSR10 and TSR10CV grades), from different Hevea brasiliensis genotypes or clones (Figure 2). However, in our study, each NR sample was made from the latex of a single clone (GT1, RRIM600 or PB235) in order to remove variability linked to the clonal origin of the latex $[11,12,31]$. The properties of the TSR3CV and TSR10CV samples were stabilized with a neutral hydroxylamine sulfate solution (NHS; Figure 2).

All samples were analysed at least 14 months after their production. Indeed, NR samples harden during storage because of the generation of macrogel $[32,33]$. It was shown that this phenomenon of storage hardening reached a plateau after about 10 to 14 months of storage according the NR grade $[32,33]$.

Before analysis, each sample was homogenized according to standards ISO 1795 and ISO 2393, on a BLERE I.F. 50 \#1400 two-roll mill (51/64 model) (Paris, France). The roll temperature was maintained at $27^{\circ} \mathrm{C}$ and the nip was $1.69 \mathrm{~mm}$. The speeds of the front and back rolls were 24 and $34 \mathrm{rpm}$, respectively.

\subsection{Separation of the soluble fraction and macrogel}

Homogenized NR samples were dissolved at $0.5 \%$ $(\mathrm{w} / \mathrm{v})$ in tetrahydrofuran (THF, HPLC grade) stabilized with $250 \mathrm{mg} / \mathrm{L}$ of 2,6-di-tert-butyl-4-methylphenol (BHT) and filtered at $0.2 \mu \mathrm{m}$. The solutions were kept at $30^{\circ} \mathrm{C}$ in the dark in a thermoregulated water bath. After 5 days, the soluble fraction and macrogel were separated by centrifugation at $30000 \mathrm{~g}$ (Beckman Coulter Avanti J-E centrifuge, Paris, France) for 1 hour at $20^{\circ} \mathrm{C}$. The upper soluble fraction was recovered and the macrogel (bottom fraction) was diluted 4 times in stabilized THF, then kept at $30^{\circ} \mathrm{C}$ in the dark for a further 2 days. The solutions were then centrifuged under the same conditions as described above. The macrogel was recovered and washed once with ultrapure water containing $5 \%(\mathrm{w} / \mathrm{v})$ of sodium dodecyl sulfate
(SDS), then washed three times with ultrapure water in order to remove non-structuring compounds precipitated with the macrogel during centrifugation [30]. After solvent evaporation, both the soluble fraction and the macrogel were finally dried at $30^{\circ} \mathrm{C}$ under vacuum for 2 hours. The macrogel content was quantified by gravimetry.

\subsection{Physico-chemical characterization \\ 2.3.1. FT-IR spectroscopy}

Sheets around $1.6 \mathrm{~mm}$ thick and with minimum roughness were prepared from homogenized samples on the same two-roll mill used for rubber homogenization. The roll temperature was maintained at $27^{\circ} \mathrm{C}$ and the nip was set to the minimum $(0.5 \mathrm{~mm})$. The speeds of the front and back rolls were 27.5 and $38.5 \mathrm{rpm}$, respectively.

FT-IR spectra were recorded on these rubber sheets with OPUS 7.0 software on a Bruker Tensor27 spectrometer (Paris, France), using the Attenuated Total Reflection (ATR) mode, in the range of 4000$400 \mathrm{~cm}^{-1}$ with a resolution of $2 \mathrm{~cm}^{-1}$ [17]. The background was measured before testing each sample. For each sample, five spectra were recorded on five different random zones of the rubber sheet. Each spectrum was obtained from 16 successive scans. Firstly, $\mathrm{H}_{2} \mathrm{O} / \mathrm{CO}_{2}$ compensation was carried out in order to overcome signals caused by atmospheric conditions in the $2400-1800 \mathrm{~cm}^{-1}$ domain. The baseline was subtracted using a rubber band correction method. A mean spectrum was then calculated from the initial five spectra. Normalization of the FT-IR spectra was performed using the maximum absorbance of the $=\mathbf{C}-\mathbf{H}$ out-of-plane bending band $\left(840 \mathrm{~cm}^{-1}\right)$, corresponding to the isoprene monomer, as previously described [17].

\subsubsection{Nitrogen contents}

Nitrogen titration is usually performed to assess the protein content of NR samples [17, 34]. The Dumas method was used to determine nitrogen contents. About $600 \mathrm{mg}$ of each homogenized sample was 
calcined at $1100^{\circ} \mathrm{C}$ under oxygen flow. Combustion gases were trapped in order to separate nitrogen oxides from dust, water vapour, halogen compounds and carbon oxides. Nitrogen oxides were reduced to $\mathrm{N}_{2}$ at $700^{\circ} \mathrm{C}$ under helium flow, on a copper column. The nitrogen content was then measured by catharometry, after calibration with well-known molecules such as EDTA, on a LECO Trumac N analyser (Paris, France). Three independent measurements were performed for each sample.

\subsubsection{Lipid characterization}

Lipid extractions were carried out according to the method given in Liengprayoon et al. [35]. Homogenized samples ( $2.8 \mathrm{~g}$ ) were ground in liquid nitrogen and lipids were extracted with a chloroform: methanol mixture $(2: 1 \mathrm{v} / \mathrm{v} ; 50 \mathrm{~mL})$ for six hours at room temperature. NR residues were removed by filtration and the solutions were evaporated to dryness. Extracts were redissolved in $4 \mathrm{~mL}$ of chloroform:methanol mixture $(2: 1 ; \mathrm{v} / \mathrm{v})$. Water soluble components were removed by adding $1 \mathrm{~mL}$ of a $0.9 \% \mathrm{NaCl}$ solution. After decantation, the lipidcontaining bottom fraction was taken and evaporated to dryness to obtain the lipid extract. The lipid extracts were expressed on a dry rubber basis. Three extraction replications were performed for the raw NR samples and their respective soluble fraction. For the macrogels, a single measurement was carried out because the quantity of the test sample was insufficient.

Neutral lipids were characterized using high performance thin layer chromatography (HPTLC). Ten micrograms of the total lipid extract was deposited on a Merck silica gel 60 F254 TLC plate $(100 \times 200 \mathrm{~mm})$ using a CAMAG Automatic TLC Sampler 4 (Muttenz, Switzerland). Elution was performed with an n-Hexane:diethyl ether:acetic acid mixture (80:20:1 $\mathrm{v} / \mathrm{v} / \mathrm{v})$. Development was carried out using a mixture of $40 \%$ orthophosphoric acid with saturated copper acetate aqueous solution in a ratio of $1: 1$ $(\mathrm{v} / \mathrm{v})$, followed by heating at $180^{\circ} \mathrm{C}$ for 10 minutes. $\beta$-sitosterol, oleic acid, $\gamma$-tocotrienol, triolein and cholesteryl stearate standards were used for identification.

\subsubsection{Swelling measurements}

Swelling measurements were carried out for each extracted macrogel, in order to estimate its crosslink density, using the Flory-Rehner equilibrium swelling equation [36]. Three independent measurements were taken for each sample. About $60 \mathrm{mg}$ of macrogel $\left(m_{\mathrm{MG}, 0}\right)$ was placed in $30 \mathrm{~mL}$ of stabilized and filtered THF. The solution was kept at $30^{\circ} \mathrm{C}$ in the dark. After 8 days, the swollen macrogel was separated from the soluble fraction with a spatula, then weighed $\left(m_{\text {swollen MG }}\right)$. Centrifugation was avoided to not modify the swelling degree of the sample. After THF evaporation, the recovered macrogel was finally dried at $30^{\circ} \mathrm{C}$ under vacuum for 2 hours, then weighed ( $\left.m_{\mathrm{dry} \mathrm{MG}}\right)$.

\section{Results and discussion \\ 3.1. Macrogel contents}

The macrogel was separated by centrifugation from the soluble fraction for $11 \mathrm{NR}$ samples, and then washed in order to eliminate non-structuring nonisoprene compounds [30]. The final recovered quantities of washed macrogel are given in Table 1. Macrogel was found to range from $1.3 \%(\mathrm{w} / \mathrm{w}$; sample H: TSR10 from PB235 latex) to $25.7 \%(\mathrm{w} / \mathrm{w}$; sample C: TSR10, RRIM600) depending on the NR sample. An influence of the grade was highlighted. Indeed, samples with high macrogel contents (14.0$25.7 \% \mathrm{w} / \mathrm{w})$ were all from TSR 10 samples [37]. On the other hand, stabilized rubbers with controlled viscosity (CV: TSR3CV and TSR10CV grades) were found to have low macrogel contents $(1.6-4.7 \%$ $\mathrm{w} / \mathrm{w})$. These results illustrate the influence of the neutral hydroxylamine sulfate (NHS) used for stabilizing these grades (Figure 2). Stabilized rubbers are less susceptible to storage hardening, unlike TSR10 samples. Storage hardening is known to increase the gel content of NR samples [6, 38]. Nevertheless, it is worth mentioning that 3 TSR 10 samples (E, H and I; Table 1) were found to have low macrogel contents $(1.3-5.2 \% \mathrm{w} / \mathrm{w})$, comparable to values of $\mathrm{CV}$ grades.

\subsection{Protein quantification}

The nitrogen atoms of NR samples mainly come from proteins and polypeptides. The nitrogen content of each sample was measured by the Dumas method, in order to estimate its protein content (Table 2). Firstly, the soluble fractions were found to have lower nitrogen contents $(0.05-0.19 \% \mathrm{w} / \mathrm{w})$ than the corresponding raw NR samples $(0.21-$ $0.50 \% \mathrm{w} / \mathrm{w})$. On the other hand, the washed macrogels were much more concentrated in nitrogen atoms than the raw NR samples. Indeed, the nitrogen con- 
Table 2. Nitrogen content of the 11 selected NR samples and their respective soluble fraction and macrogel, measured with the Dumas method (Sol - Soluble fraction; MG - Macrogel. Values in brackets are the standard deviations obtained from 3 independent measurements. Material balances were calculated from the macrogel amounts. Sol [\%] = $100-\mathrm{MG}[\%]$. The protein concentrations $\left(W_{\mathrm{P}}\right)$ of the macrogel samples were calculated considering that nitrogen accounts for $16 \%(\mathrm{w} / \mathrm{w})$ of the proteins.)

\begin{tabular}{|c|c|c|c|c|c|c|c|c|c|}
\hline \multirow{2}{*}{ Sample } & \multirow{2}{*}{ Grade-Clone } & \multirow{2}{*}{$\begin{array}{c}\text { Macrogel } \\
\text { amount } \\
{[\% \mathrm{w} / \mathrm{w}]}\end{array}$} & \multicolumn{3}{|c|}{$\begin{array}{c}\text { Nitrogen content } \\
{[\% \mathrm{w} / \mathrm{w}]}\end{array}$} & \multicolumn{3}{|c|}{ Nitrogen balance } & \multirow{2}{*}{$\begin{array}{c}\text { Protein } \\
\text { concentration } \\
\left(W_{\mathrm{P}}\right) \text { in MG } \\
{[\% \mathrm{w} / \mathbf{w}]}\end{array}$} \\
\hline & & & Raw NR & Sol & MG & Sol & MG & $\begin{array}{c}\text { Lost } \\
\text { nitrogen }\end{array}$ & \\
\hline A & TSR10 - GT1 & 14.0 & $0.296(0.002)$ & $122(0.002)$ & $1.181(0.019)$ & $35.4 \%$ & $55.8 \%$ & $-8.8 \%$ & $7.38(0.12)$ \\
\hline B & TSR10 - GT1 & 15.4 & $0.278(0.006)$ & $0.057(0.002)$ & $0.909(0.029)$ & $17.3 \%$ & $50.3 \%$ & $-32.4 \%$ & $5.68(0.18)$ \\
\hline $\mathrm{C}$ & TSR10 - RRIM600 & & $254(0.006)$ & $0.055(0.003)$ & $0.743(0.014)$ & $16.2 \%$ & $75.2 \%$ & & $4.64(0.09)$ \\
\hline $\mathrm{D}$ & TSR10 - RRIM600 & 20.8 & $0.298(0.007)$ & $0.062(0.014)$ & $1.170(0.025)$ & $16.4 \%$ & $81.7 \%$ & $-1.9 \%$ & $7.31(0.16)$ \\
\hline $\mathrm{E}$ & TSR10 - GT1 & 5.2 & $0.293(0.002)$ & $0.165(0.013)$ & $2.216(0.177)$ & $53.3 \%$ & $39.3 \%$ & $-7.4 \%$ & $(1.1)$ \\
\hline $\mathrm{F}$ & TSR10CV - GT1 & 4.7 & $0.269(0.011)$ & $0.118(0.021)$ & $2.191(0.071)$ & $41.8 \%$ & $38.2 \%$ & $-20.0 \%$ & $13.7 \quad(0.44)$ \\
\hline G & TSR10CV - GT1 & 2.1 & $0.336(0.009)$ & $0.194(0.012)$ & $4.391(0.204)$ & $56.6 \%$ & $27.4 \%$ & $-16.0 \%$ & $(1.3)$ \\
\hline $\mathrm{H}$ & TSR10 - PB235 & 1.3 & $0.208(0.002)$ & $0.139(0.041)$ & $3.717(0.196)$ & $65.9 \%$ & $23.3 \%$ & $-10.8 \%$ & $(1.2)$ \\
\hline I & TSR10 - GT1 & 2.8 & $0.332(0.008)$ & $0.180(0.011)$ & $5.228(0.185)$ & $52.6 \%$ & $44.1 \%$ & $-3.3 \%$ & $(1.2)$ \\
\hline $\mathrm{J}$ & TSR3CV - GT1 & 3.6 & $0.436(0.004)$ & $0.128(0.003)$ & $5.935(0.040)$ & $28.3 \%$ & $49.0 \%$ & $-22.7 \%$ & $37.1 \quad(0.25)$ \\
\hline K & TSR3CV - GT1 & 1.6 & $0.496(0.008)$ & $0.129(0.001)$ & $8.121(0.152)$ & $25.6 \%$ & $26.2 \%$ & $-48.2 \%$ & $50.8 \quad(0.95)$ \\
\hline
\end{tabular}

tents of the 11 macrogels were between $0.74 \%$ and $8.12 \%(\mathrm{w} / \mathrm{w})$. These concentrations correspond to protein contents $\left(W_{\mathrm{P}}\right)$ of 4.6 to $50.8 \%(\mathrm{w} / \mathrm{w})$, calculated with a conventional value of $16 \%(\mathrm{w} / \mathrm{w})$ of nitrogen atoms in proteins (Table 2). It is worth noting that the 2 macrogels with the highest nitrogen contents (Samples J and K: 5.94-8.12\% w/w) were extracted from the $2 \mathrm{TSR} 3 \mathrm{CV}$ samples. Otherwise, the 4 macrogels with the lowest nitrogen contents (Samples A-D: $0.74-1.18 \% \mathrm{w} / \mathrm{w}$ ) came from the TSR 10 samples with high macrogel contents (Table 2).

These results confirmed that proteins are highly concentrated in the macrogel of NR, during the centrifugation step, in accordance with the literature [2729]. However, it is important to note that most of the proteins in the raw NR sample were not always found in the macrogel (Table 2). In fact, only 4 of the 11 macrogels accounted for more than $50 \%$ of the initial nitrogen atoms contained in the raw NR samples. Moreover, the nitrogen concentrations measured for the soluble fractions were far from negligible. For example, in the case of sample H (TSR10, PB235), only $23 \%$ of the initial nitrogen atoms were found in the macrogel, while the soluble fraction accounted for $66 \%$ of the initial nitrogen atoms. As it is known that microgel remains in the soluble fraction, it can be assumed that the proteins found in the soluble fraction take part in structuring microaggregates. It should be noted that material losses were calculated and accounted for 2 to $48 \%$ of the initial nitrogen atoms contained in the raw NR sam- ples (Table 2). Those nitrogen losses were attributed to non-structuring proteins, eliminated during the macrogel washing steps, as reported previously [30]. The remaining proteins contained in the washed macrogels were not eliminated during the washing steps, and were assumed to participate in macrogel structuring. No correlation was found between the macrogel content and the nitrogen content of the raw NR samples.

FT-IR spectroscopy in ATR configuration can be used to quickly characterize NR samples, and to estimate some non-isoprene compound concentrations [17]. Proteins show characteristic vibration bands at $3283 \mathrm{~cm}^{-1} \quad(v \mathbf{N}-\mathbf{H}), \quad 1630 \mathrm{~cm}^{-1} \quad$ (Amide I: $v-(\mathbf{C}=\mathbf{O}) \mathrm{NH}-$ ) and $1541 \mathrm{~cm}^{-1}$ (Amide II: $\beta \mathbf{N}-\mathbf{H}+$ $v \mathbf{C}-\mathbf{N})$. Figure 3 shows the normalized FT-IR spectra of a TSR10 sample made from GT1 latex (Sample I) and of its respective soluble fraction and washed macrogel. The maximum normalized absorbances of the amide vibration bands (1630 and $1541 \mathrm{~cm}^{-1}$ ) were found to be more than 15 times higher for the macrogel sample, compared to the raw NR sample and the soluble fraction. These two amide bands were previously correlated to the nitrogen content of raw NR samples [17]. It is interesting to note that these correlations also existed for the macrogel samples (Figure 4). Indeed, the maximum normalized absorbance of the amide I vibration band $\left(1630 \mathrm{~cm}^{-1}\right)$ increased linearly with the nitrogen content $\left(R^{2}=0.97\right)$ of the studied macrogels, except for the one extracted from sample K. 

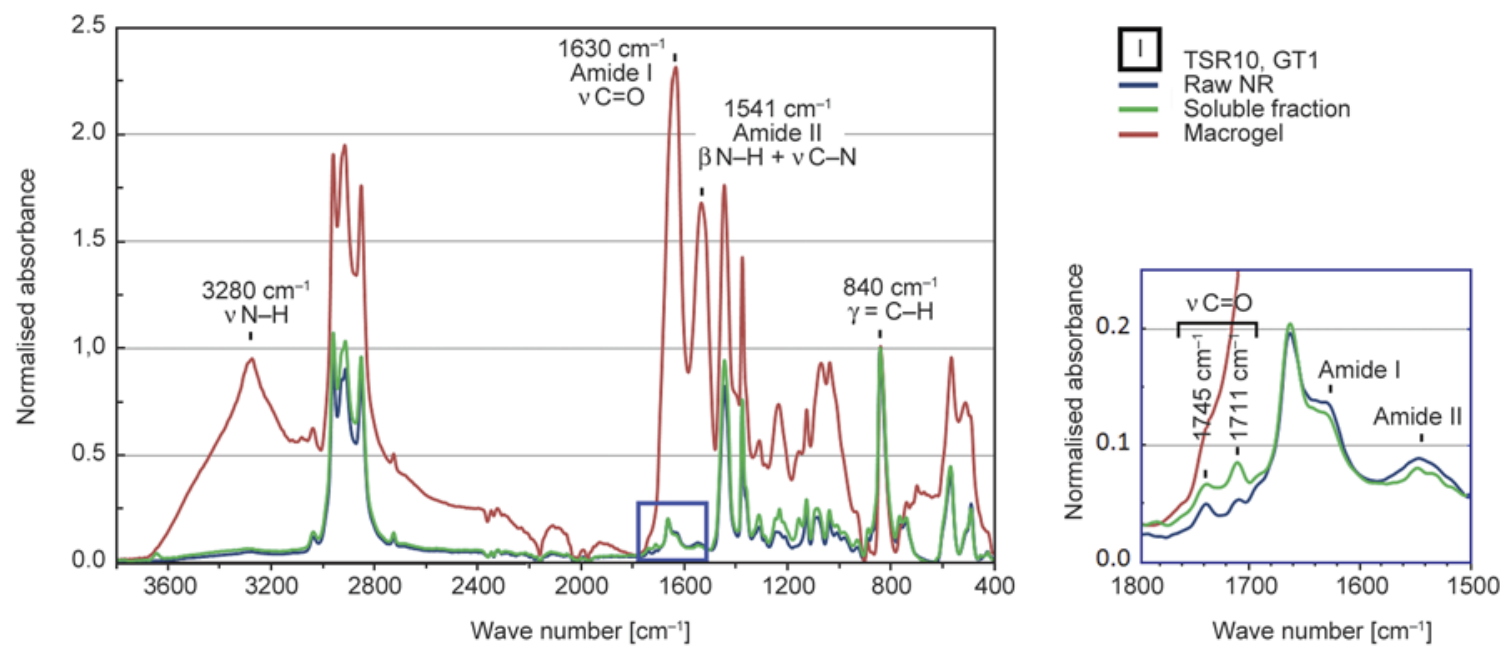

Figure 3. Normalized FT-IR spectra of a TSR10 sample made from the latex of clone GT1 (Sample I) and of its separated soluble fraction and washed macrogel

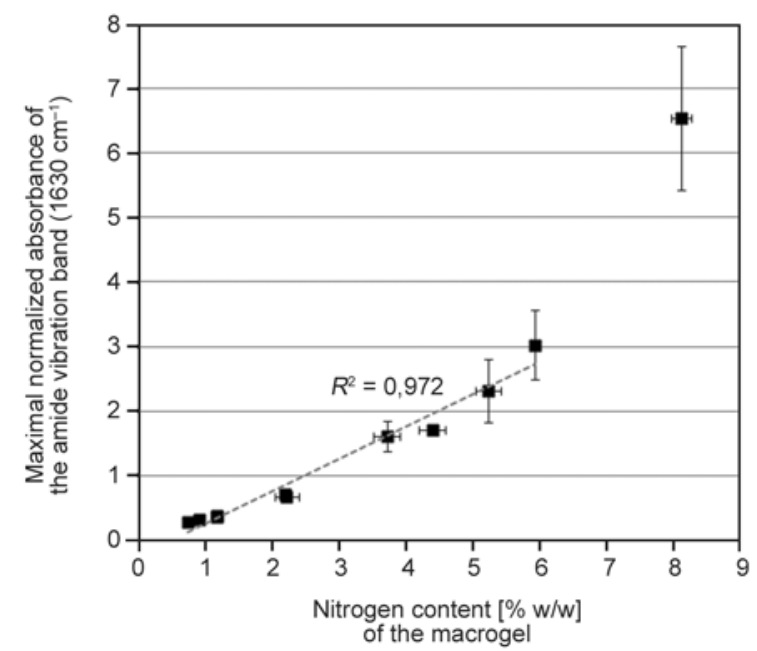

Figure 4. Evolution of the maximum absorbance of the amide I vibration band $\left(1630 \mathrm{~cm}^{-1}\right)$ normalized by the maximum absorbance of the cis-1,4-isoprene band $\left(840 \mathrm{~cm}^{-1}\right)$, with the nitrogen content of the washed macrogels. The macrogel with the highest nitrogen content (Sample K, N: 8.12\% w/w) was not taken into account in the linear model.

For this sample, containing the highest nitrogen content $(8.12 \% \mathrm{w} / \mathrm{w}$, Table 2$)$, normalization with the maximum absorbance of the cis-1,4-isoprene monomer $\left(840 \mathrm{~cm}^{-1}\right)$ could be inappropriate.

\subsection{Lipid characterization}

Lipids of NR samples can also be studied using FTIR spectroscopy. Esterified lipids and free fatty acids (carboxylic acids) show intense carbonyl stretching bands in the 1748-1738 $\mathrm{cm}^{-1}$ domain $(v-(\mathbf{C}=\mathbf{O}) \mathrm{OR})$ and at $1710 \mathrm{~cm}^{-1}(v-(\mathbf{C}=\mathbf{O}) \mathrm{OH})$, respectively [17]. For all samples, the maximum normalized absorbances of the respective lipid bands (esters:
1748-1738 $\mathrm{cm}^{-1}$; carboxyls: $1710 \mathrm{~cm}^{-1}$ ), were higher for the soluble fraction than for the raw NR sample, indicating that lipids were probably concentrated in the soluble fraction during NR dissolution (Figure 3). On the other hand, no distinct ester or carboxyl band was observable for the majority of the macrogel samples. However, the high amide vibration bands may have masked the other carbonyl stretching bands and lipids might yet be present in the macrogel composition.

Lipids were extracted for two TSR10 samples with large amounts of macrogel (Samples A and C) and for their respective soluble fraction and washed macrogel, according to the method given by Liengprayoon et al. [35]. The selected samples A and C were made from the latex of clones GT1 and RRIM600, respectively (Table 1). The quantity of extractable lipids in the two raw NR samples was found to account for $2.63 \%$ (A: GT1) and $2.09 \%$ (C: RRIM600) of the material weight (Table 3). NR samples from RRIM600 latex usually have lower lipid extracts $[16,17]$. The lipid extract was higher for the soluble fractions (A: $5.25 \% \mathrm{w} / \mathrm{w} ; \mathrm{C}: 5.53 \% \mathrm{w} / \mathrm{w}$ ), while both macrogels showed much lower extracts, between $0.51 \%(\mathrm{~A})$ and $0.58 \% \mathrm{w} / \mathrm{w}(\mathrm{C})$. These observations tallied well with the FT-IR spectra (Figure 3) and indicated a concentration of the lipid molecules in the soluble fraction of NR samples.

Material balances were calculated by using the respective proportion of each fraction (soluble fraction and macrogel) in the corresponding raw NR sample (Table 3). A clear overage of extracted material was highlighted for both soluble fractions. In fact, the lipid extracts of the two soluble fractions amounted 
Table 3. Lipid extract of two TSR 10 samples made from the latex of clones GT1 (A) and RRIM600 (C), and of their respective soluble fraction and macrogel (Sol - Soluble fraction; MG - Macrogel. Values in brackets are the standard deviations obtained from 3 independent measurements. Material balances were calculated from the macrogel amounts. Sol [\%] $=$ $100-\mathrm{MG}[\%]$.)

\begin{tabular}{|c|c|c|c|c|c|c|c|c|}
\hline \multirow{2}{*}{ Sample } & \multirow{2}{*}{ Grade-Clone } & \multirow{2}{*}{$\begin{array}{c}\text { Macrogel } \\
\text { amount } \\
{[\% \mathrm{w} / \mathrm{w}]}\end{array}$} & \multicolumn{3}{|c|}{$\begin{array}{c}\text { Lipid extract } \\
{[\% \mathrm{w} / \mathrm{w}]}\end{array}$} & \multicolumn{3}{|c|}{ Material balance } \\
\hline & & & Raw NR & Sol & MG & Sol & MG & Overage \\
\hline A & TSR10 - GT1 & 14.0 & $2.63(0.11)$ & $5.25(0.49)$ & $0.51-$ & $172 \%$ & $3 \%$ & $74 \%$ \\
\hline $\mathrm{C}$ & TSR10 - RRIM600 & 25.7 & $2.09(0.08)$ & $5.53(0.22)$ & $0.58-$ & $197 \%$ & $7 \%$ & $104 \%$ \\
\hline
\end{tabular}

to between 172\% (A: GT1) and 197\% (C: RRIM600) of the lipid extracts of the raw NR samples. Simultaneous extraction of $c i s-1,4$-polyisoprene chains might explain these overages.

Each lipid extract was then characterized using HPTLC, with a mobile phase optimized for the elution of neutral lipids which are known to account for $83-86 \%$ of the total lipids of NR [16]. A calibration with well-known lipid standards was used to identify some substances (Figure 5). Both raw NR samples (A: GT1; C: RRIM600) showed the same neutral lipid composition. Free sterols $\left(R_{\mathrm{f}}=0.15\right)$ were identified for the two samples. Unidentified substances with an $R_{\mathrm{f}}$ value of 0.06 were also found. Several free fatty acids (FFAs) were identified: at least two bands with an $R_{\mathrm{f}}$ value close to that of oleic acid $\left(\mathrm{C} 18: 1 ; R_{\mathrm{f}}=0.21\right)$ were attributed to furan fatty acids (FuFAs; $\left.R_{\mathrm{f}}=0.19\right)$ and to other FFAs $\left(R_{\mathrm{f}}=0.22\right)$ [16]. $\gamma$-tocotrienol $\left(R_{\mathrm{f}}=0.30\right)$ was also found. Substances with an $R_{\mathrm{f}}$ value between $\gamma$ tocotrienol $\left(R_{\mathrm{f}}=0.30\right)$ and triolein $\left(R_{\mathrm{f}}=0.57\right)$ may

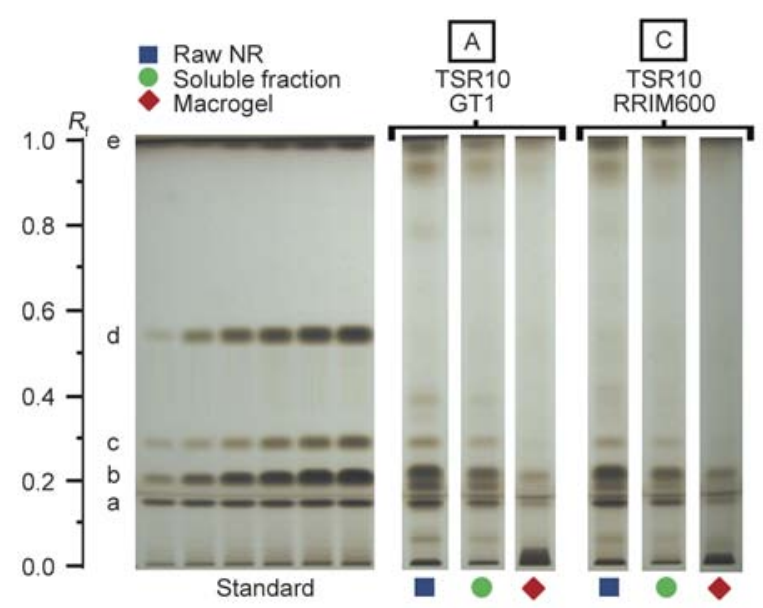

Figure 5. HPTLC analyses of the lipid extracts obtained from two TSR10 samples made from the latex of clones GT1 (A) and RRIM600 (C), and from their respective soluble fraction and macrogel, using standard calibrations: $\beta$-sitosterol (a); oleic acid (b); $\gamma$-tocotrienol (c); triolein (d); cholesteryl stearate (e) have been $\alpha$-tocotrienol or triglycerides. Those bands showed low intensity, according to previous observations carried out on TSR10 samples [17]. Lastly, some other bands with an $R_{\mathrm{f}}$ value over 0.90 were attributed to esterified tocotrienols and esterified sterols [16].

All the substances identified in the raw NR samples were also found in the lipid extracts of both soluble fractions (Figure 5). Nevertheless, for the soluble fractions, the neutral lipid bands showed lower intensities, indicating lower concentrations in the corresponding lipid extracts. This result supports the idea of co-extraction of cis-1,4-polyisoprene during lipid extraction, leading to an overestimation of the lipid extract. In fact, the share of extractable lipids in the soluble fractions was probably lower than $5.25-5.53 \% \mathrm{w} / \mathrm{w}$. On the other hand, the HPTLC analyses of the two macrogel lipid extracts revealed very few bands (Figure 5), corresponding to free sterols $\left(R_{\mathrm{f}}=0.15\right)$ and to FFAs $\left(R_{\mathrm{f}}=0.22\right)$. The previous esterified substances (triglycerides, esterified tocotrienols and esterified sterols) were not detected for either macrogel. It is important to note the existence of high concentrations of polar substances $\left(R_{\mathrm{f}}<0.04\right)$ in the macrogel lipid extracts. These substances could be attributed to polar lipids but also to hydrophobic proteins, co-extracted with the lipids and not eliminated during the Folch-wash step. The presence of those polar substances indicated that the extractable neutral lipids contained in both macrogels might amount to less than $0.51 \%$ (A: GT1) and $0.58 \%$ (C: RRIM600).

It needs to be remembered that for these two macrogels the measured nitrogen contents were $1.18 \%$ (w/w; A: GT1; Table 2) and $0.74 \%(w / w ; C$ : RRIM600), corresponding to protein concentrations of about 7.4 and $4.6 \%(\mathrm{w} / \mathrm{w})$, respectively. Consequently, the quantities of extractable lipids were clearly much lower than the proteins in these two samples. Moreover, the two macrogels were among those with the lowest protein concentrations (Table 2). 

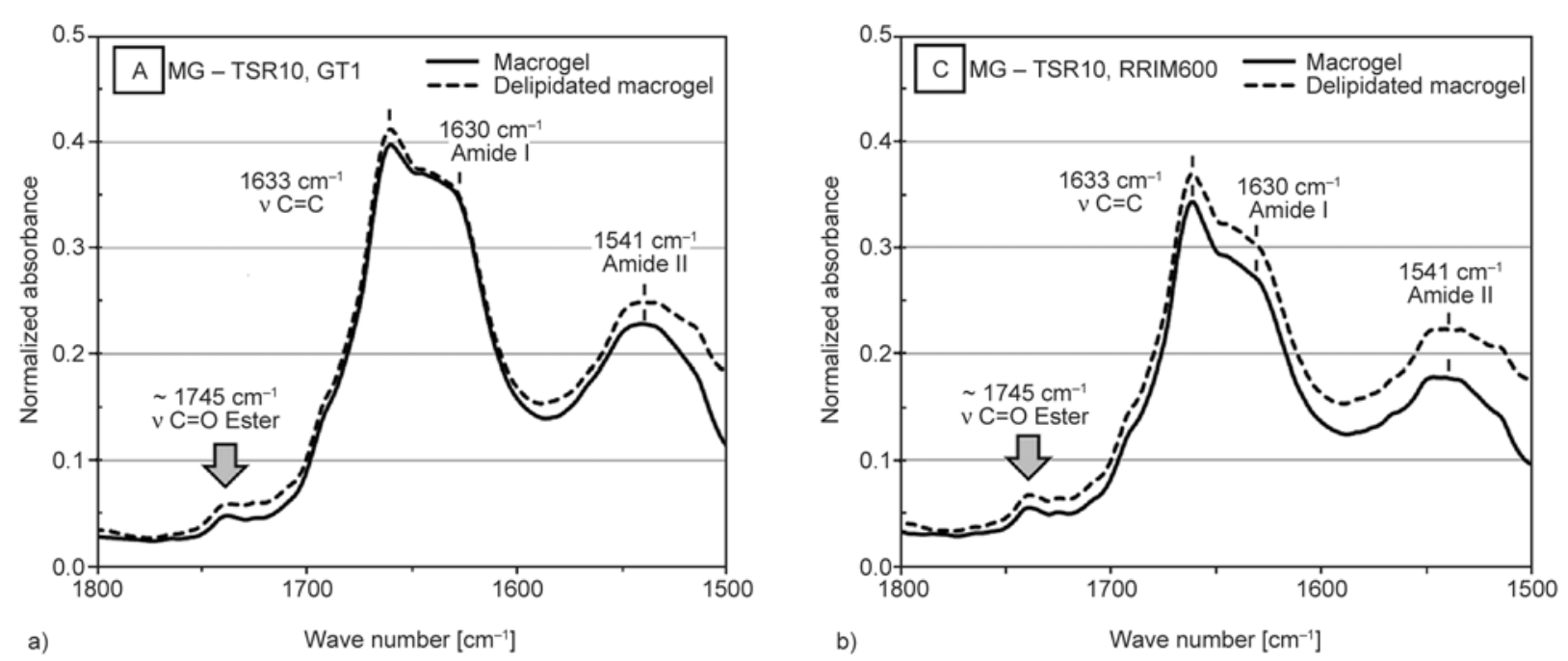

Figure 6. Normalized FT-IR spectra of the macrogels of two TSR10 samples made from latex of clones GT1 (a) and RRIM600 (b), before and after lipid extraction

For all macrogels, the share of extractable lipids could probably be neglected compared to the protein concentrations, which were estimated to be 4.6 to $50.8 \%(\mathrm{w} / \mathrm{w})$. The role of proteins in macrogel structuring is probably predominant. However, it is worth noting that the method given by Liengprayoon et al. [35] can only be used to study extractable lipids. Non-extractable esters [17] might partly be responsible for the associative structure of NR, as suggested by Tanaka and coworkers [21, 22]. FT-IR characterization of the two macrogels showed the presence of non-extractable esters (Figure 6). A calibration curve obtained with mixtures of synthetic cis-1,4-polyisoprene (Nipol IR2200, Zeon Chemicals) with well-known amounts of methyl stearate [17], enabled an estimation of those non-extractable esters, which were found to amount to 4.5 (sample A) and $9.0 \mathrm{mmol} / \mathrm{kg}$ (sample C) in the macrogels.

\subsection{Role of proteins in the crosslink density of the macrogels}

Swelling was also measured for the 11 washed macrogels, in order to evaluate their respective crosslink density [36]. The change in weight of the swollen macrogel after drying was first used to calculate the swelling degree of the cis-1,4-polyisoprene fraction $\left(Q_{\mathrm{PI}}\right)$ of the macrogel (Equation (1)). In this model, the proteins of the macrogel, which were assumed to account for the majority of the non-isoprene compounds, were also considered but were unable to swell because of their insolubility in organic solvents. The protein concentrations $\left(W_{\mathrm{P}}\right)$ in the washed macrogel (Table 2) were used for this calculation.
For the 11 macrogels, the swelling degree of the cis1,4-polyisoprene fraction ( $\left.Q_{\mathrm{PI}}\right)$ was found to vary between 6.6 (Sample K: TSR3CV, GT1; Table 4) and 85.7 (Sample A: TSR10, GT1). These values indicate that the volume of THF ( $\left.V_{\mathrm{THF}}\right)$ in the swollen macrogels was 6.6 to 85.7 times greater than the volume of the cis-1,4-polyisoprene chains $\left(V_{\mathrm{PI}}\right)$. It is worth mentioning that both macrogels extracted from the two TSR3CV samples (Samples J and K) had the lowest $Q_{\text {PI }}$ values (Table 4). On the other hand, the 4 macrogels extracted from samples A to $\mathrm{D}$, which showed high macrogel contents, had the highest $Q_{\mathrm{PI}}$ values (Equation (1)):

$$
\begin{aligned}
& Q_{\mathrm{PI}}=\frac{V_{\mathrm{THF}}}{V_{\mathrm{PI}}}= \\
& =\frac{m_{\text {swollen } \mathrm{MG}}-m_{\mathrm{dry} \mathrm{MG}}}{\rho_{\mathrm{THF}}} \cdot \frac{\rho_{\mathrm{PI}}}{m_{\mathrm{dry} \mathrm{MG}} \cdot\left(1-W_{\mathrm{P}}\right)}
\end{aligned}
$$

where $Q_{\mathrm{PI}}-$ swelling degree of the cis-1,4-polyisoprene fraction, $V_{\mathrm{THF}}$ - volume of THF in the swollen macrogel, $V_{\mathrm{PI}}-$ volume of cis-1,4-polyisoprene in the swollen macrogel, $m_{\text {swollen MG }}$ - weight of the swollen macrogel, $m_{\mathrm{dry} \mathrm{MG}}-$ weight of the macrogel after drying, $\rho_{\mathrm{THF}}-$ density of THF $\left(0.887 \mathrm{~g} / \mathrm{cm}^{3}\right)$, $\rho_{\mathrm{PI}}-$ density of $c i s-1,4$-polyisoprene $\left(0.910 \mathrm{~g} / \mathrm{cm}^{3}\right)$, $W_{\mathrm{P}}$ - mass fraction of proteins in the macrogel (Table 2).

The calculated swelling degree $\left(Q_{\mathrm{PI}}\right)$ was then used to estimate the mean molar mass of cis-1,4-polyisoprene between crosslinks $\left(M_{\mathrm{c}}\right)$ for each macrogel, using the Flory-Rehner [36] equilibrium swelling equation (Equation (2)). The lowest mean molar mass 
of cis-1,4-polyisoprene between crosslinks $\left(M_{\mathrm{c}}=\right.$ $22 \mathrm{~kg} / \mathrm{mol}$; Table 4) was measured for the macrogel of sample K (TSR3CV, GT1), indicating that this macrogel was the most crosslinked. Indeed, a $M_{\mathrm{c}}$ value of $22 \mathrm{~kg} / \mathrm{mol}$ corresponds to only 320 isoprene monomers between crosslinks. On the other hand, the macrogel extracted from sample A (TSR10, GT1) had a $M_{\mathrm{c}}$ value of $1985 \mathrm{~kg} / \mathrm{mol}$, corresponding to about 30000 monomer units, and was the least crosslinked macrogel. The other macrogels showed intermediate $M_{\mathrm{c}}$ values (Table 4). Tangpakdee and Tanaka [34] already calculated the mean molar mass of cis-1,4-polyisoprene between crosslinks $\left(M_{\mathrm{c}}\right)$ for 3 macrogels extracted from a commercial NR sample and from two films of high-ammonia preserved latex. The authors found $M_{\mathrm{c}}$ values between 730 and $1100 \mathrm{~kg} / \mathrm{mol}$. However, they considered that their macrogel was only composed of cis-1,4-polyisoprene: they did not take into account the high protein contents (from 4.6 to $50.8 \% \mathrm{w} / \mathrm{w}$ for our samples, Table 2). Our results showed that macrogels extracted from commercial NR samples can be very diverse and more or less crosslinked compared to those studied by Tangpakdee and Tanaka [34]. An influence of the grade was also highlighted: the two macrogels extracted from TSR3CV samples were found to be the most crosslinked, with $M_{\mathrm{c}}$ values of 22 (sample K) and $37 \mathrm{~kg} / \mathrm{mol}$ (sample J). On the other hand, all the macrogels from TSR 10 and TSR $10 \mathrm{CV}$ showed $M_{\mathrm{c}}$ values over $100 \mathrm{~kg} / \mathrm{mol}$ (Table 4). The crosslink density $\left(M_{\mathrm{c}}^{-1}\right)$ of all macrogels was calculated as the inverse of the mean molar mass of cis- 1,4-polyisoprene between crosslinks $\left(M_{\mathrm{c}}\right)$, and was found to vary between 0.51 (sample A) and $46.6 \mathrm{mmol} / \mathrm{kg}$ (sample K; Table 4). This parameter represents the quantity of crosslinks per kilogram of cis-1,4-polyisoprene.

It should be noted that the quantities of macrogel recovered after swelling were always lower than the initial quantities $\left(m_{\mathrm{MG}, 0}\right)$ used for swelling measurements (Table 4). The recovered macrogel accounted for 52.8 to $98.5 \%$ of the initial macrogel, indicating the presence of a fraction structured by physical interactions, probably composed of microaggregates. An increase in crosslink density $\left(M_{\mathrm{c}}{ }^{-1}\right)$ led to a decrease in the proportion of soluble fraction in the studied macrogel (Equation (2)):

$$
M_{\mathrm{c}}=\rho_{\mathrm{PI}} \cdot V_{0} \cdot \frac{0.5 \cdot v_{\mathrm{PI}}-\sqrt[3]{v_{P I}}}{\ln \left(1-v_{\mathrm{PI}}\right)+v_{\mathrm{PI}}+\chi v_{\mathrm{PI}}^{2}}
$$

where $M_{\mathrm{c}}$ - mean molar mass of cis-1,4-polyisoprene between crosslinks in the macrogel, $\rho_{\mathrm{PI}}-$ density of cis-1,4-polyisoprene $\left(0.910 \mathrm{~g} / \mathrm{cm}^{3}\right), V_{0}$ - molar volume of THF $\left(81.30 \mathrm{~cm}^{3} / \mathrm{mol}\right), \chi-\mathrm{NR}-\mathrm{THF}$ interaction parameter $(0.442)$ [39], $v_{\mathrm{PI}}-$ volume fraction of cis-1,4-polyisoprene in the swollen macrogel (Equation (3)):

$$
\frac{1}{v_{\mathrm{PI}}}=\frac{V_{\mathrm{THF}}+V_{\mathrm{PI}}+V_{\mathrm{P}}}{V_{\mathrm{PI}}}=Q_{\mathrm{PI}}+1+\frac{W_{\mathrm{P}} \cdot \rho_{\mathrm{PI}}}{\left(1-W_{\mathrm{P}}\right) \cdot \rho_{\mathrm{P}}}
$$

where $v_{\mathrm{PI}}$ - volume fraction of cis-1,4-polyisoprene in the swollen macrogel, $V_{\mathrm{THF}}$ - volume of THF in the swollen macrogel, $V_{\mathrm{PI}}-$ volume of $c i s$-1,4-poly-

Table 4. Evaluation of the crosslink density $\left(M_{\mathrm{c}}^{-1}\right)$ of different macrogels extracted from $11 \mathrm{NR}$ samples, using swelling measurements (Values in brackets are the standard deviations obtained from 3 independent measurements. For

\begin{tabular}{|c|c|c|c|c|c|c|}
\hline Macrogel & Grade - Clone & $\begin{array}{c}\text { Recovered } \\
\text { macrogel } \\
\text { after swelling } \\
{[\% \mathrm{w} / \mathrm{w}]}\end{array}$ & \begin{tabular}{|c|}
$Q_{\text {PI }}$ \\
Swelling degree of \\
the cis-1,4- \\
polyisoprene \\
fraction \\
(See Equation (1))
\end{tabular} & $\begin{array}{c}M_{\mathrm{c}} \\
{[\mathrm{kg} / \mathrm{mol}]} \\
\text { Mean molar mass of } \\
\text { cis-1,4-polyisoprene } \\
\text { between crosslinks } \\
\text { (See Equation }(2))\end{array}$ & $\begin{array}{c}\text { Quantity of } \\
\text { isoprene units } \\
\text { between crosslinks } \\
\left(=M_{\mathrm{c}} / 68 \mathrm{~g} / \mathrm{mol}\right)\end{array}$ & $\begin{array}{c}\text { Crosslink } \\
\text { density } \\
\text { [mmol/kg] } \\
\left(=1 / M_{\mathrm{c}}\right)\end{array}$ \\
\hline $\mathrm{A}$ & TSR10 - GT1 & $52.8(0.8)$ & $85.7 \quad(6.6) \mathrm{a}$ & $1985(265) \mathrm{a}$ & $29196(3897)$ & $0.51(0.07)$ \\
\hline B & TSR10 - GT1 & $54.2(0.9)$ & 73.7 (12.8) a,b & 1544 (463) a,b & $22703(6808)$ & $0.69(0.20)$ \\
\hline $\mathrm{C}$ & TSR10 - RRIM600 & $59.6(1.3)$ & $68.0 \quad(6.7) \mathrm{b}$ & $1332(233) b$ & $19592(3425)$ & $0.76(0.12)$ \\
\hline $\mathrm{D}$ & TSR10 - RRIM600 & $63.7(2.0)$ & $63.8 \quad(7.2) b$ & $1193(234) b$ & $17543(3469)$ & $0.86(0.16)$ \\
\hline $\mathrm{E}$ & TSR10 - GT1 & $75.1(1.6)$ & $43.4 \quad(1.4) \mathrm{c}$ & $605 \quad(34) \mathrm{c}$ & $8891 \quad$ (499) & $1.66(0.09)$ \\
\hline F & TSR10CV - GT1 & $71.2(5.6)$ & $39.6 \quad(2.4) \mathrm{c}$ & $515 \quad(55) d$ & $7580 \quad(813)$ & $1.96(0.22)$ \\
\hline G & TSR10CV - GT1 & $80.8(1.4)$ & $22.0 \quad(1.7) \mathrm{d}$ & $181 \quad(26) \mathrm{e}$ & $2665 \quad(380)$ & $5.59(0.79)$ \\
\hline $\mathrm{H}$ & TSR10 - PB235 & $88.0(0.9)$ & $19.3 \quad(1.6) \mathrm{d}, \mathrm{e}$ & $142 \quad(22) \mathrm{e}$ & $2082 \quad(328)$ & $7.18(1.09)$ \\
\hline I & TSR10 - GT1 & $91.0(0.8)$ & $16.5 \quad(1.3) \mathrm{e}$ & 108 (16) e & $1583 \quad(228)$ & $9.43(1.48)$ \\
\hline $\mathrm{J}$ & TSR3CV - GT1 & $91.7(2.1)$ & $9.2 \quad(0.9) \mathrm{f}$ & (7) $\mathrm{f}$ & (96) & $27.4(4.36)$ \\
\hline $\mathrm{K}$ & TSR3CV - GT1 & $98.5(0.4)$ & $6.6 \quad(0.6) \mathrm{f}$ & (3) $\mathrm{f}$ & $(51)$ & $46.6(6.91)$ \\
\hline
\end{tabular}
each column, values with the same letter are not significantly different $(p=0.05)$.) 


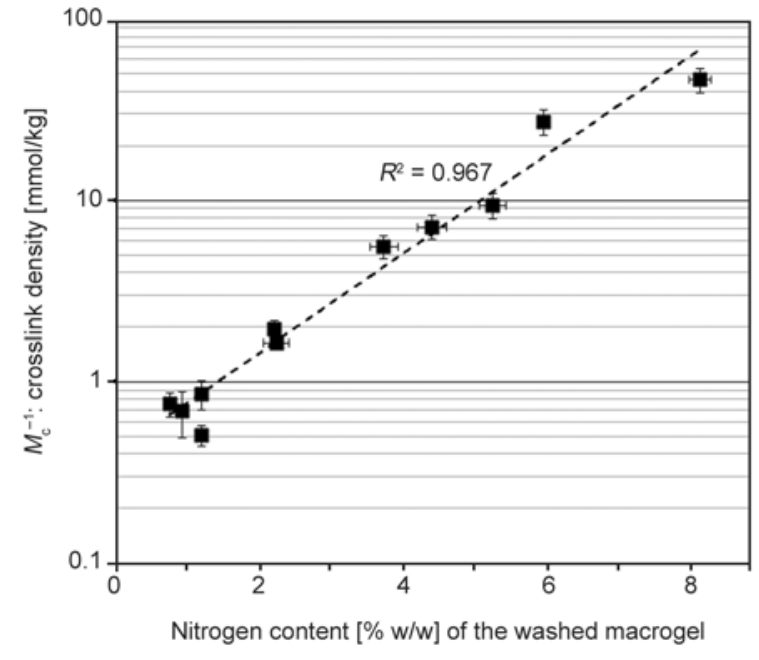

Figure 7. Relation between the nitrogen content of the macrogel and its crosslink density $\left(M_{\mathrm{c}}^{-1}\right)$ estimated by swelling measurements

isoprene in the swollen macrogel, $V_{\mathrm{P}}$ - volume of proteins in swollen macrogel, $W_{\mathrm{P}}-$ mass fraction of proteins in the macrogel (Table 2), $\rho_{\mathrm{PI}}$ - density of cis-1,4-polyisoprene $\left(0.910 \mathrm{~g} / \mathrm{cm}^{3}\right), \rho_{\mathrm{P}}-$ mean density of proteins $\left(1.37 \mathrm{~g} / \mathrm{cm}^{3}\right)$.

Figure 7 shows the changes in crosslink density $\left(M_{\mathrm{c}}^{-1}\right)$ for the 11 macrogels, with their respective nitrogen contents measured by the Dumas method. Interestingly, the crosslink density of a macrogel exponentially increases with its protein concentration $\left(R^{2}=0.967\right)$. Several studies have already suggested that proteins are partly responsible for the presence of macrogel in NR samples [14, 21]. Our results showed that proteins play a major role in the structuring of a macrogel, and seem to be involved in the majority of crosslinks. The influence of esterified lipids on the presence of macrogel has also been reported [21, 22]. In this paper, we have shown that extractable lipids amounted to less than $0.5 \%$ $(w / w)$ for macrogels with low protein concentrations and could be neglected compared to proteins. Nevertheless, non-extractable ester functional groups were found to be present in the studied macrogels $(0.13-0.27 \% \mathrm{w} / \mathrm{w}$; Figure 6$)$, indicating that lipids might play a minor role in macrogel structuring. One way to ensure that these non-extractable esters were from lipids would be to extract them after transesterification.

\section{Conclusions}

Eleven natural rubber (NR) samples of TSR grades (TSR10, TSR10CV and TSR3CV) made from the latex of 3 different clones (GT1, RRIM600 and
PB235) were studied. Their respective macrogel and soluble fraction were separated. The protein content and lipid composition of each fraction were investigated. The majority of the non-isoprene compounds of the macrogel were found to be nitrogen-containing compounds. The protein content was estimated to account for 4.6 to $50.8 \%$ of the macrogel weight. Our results also showed that the soluble part contained large quantities of proteins: from 16 to $66 \%$ of the protein content of the raw NR sample before fractionation. These proteins were assumed to participate in the structuring of microaggregates present in the soluble fraction. Unlike proteins, very few extractable lipids were found in macrogel, amounting to less than $0.5 \%(\mathrm{w} / \mathrm{w})$ of the macrogel.

The crosslink density of each macrogel was estimated by swelling measurements. A correlation between the protein contents of the 11 macrogels and their respective protein concentrations was highlighted $\left(R^{2}>0.96\right)$. NR macrogel structuring was clearly correlated to the amount of proteins, suggesting that proteins are involved in the majority of crosslinks. Moreover, the grade was found to have an influence, as the macrogels extracted from the TSR3CV samples were more crosslinked and also had a higher protein concentration than the macrogels from TSR10 and TSR10CV samples.

\section{Acknowledgements}

This work was part of the CANAOPT project, which aims to develop new grades of NR with reduced and controlled variability, for anti-vibration applications. The authors would like to thank the members of the CANAOPT project: Hutchinson, Anvis, Emac, Metaldyne, Michelin, the LRCCP and the Université du Maine. Thanks to our local partners: S.A.P.H. (Côte d'Ivoire), Thai Hua (Thailand) and Dau Tieng Corporation (Vietnam). Thanks to the French public investment bank (BPI), to the French regions and departments of Bourgogne (CR), Pays de la Loire (CR), Languedoc-Roussillon (FEDER), Loiret (CG45), Nièvre (CG58) and PyrénéesAtlantiques (CG64), and to the Montargis agglomeration for their financial support.

\section{References}

[1] International Rubber Study Group: Rubber Statistical Bulletin, April - June 2015 (2015).

[2] Fuller K. N. G.: Rheology of raw rubber. in 'Natural rubber science and technology’ (ed.: Roberts A. D.) Oxford University Press, Oxford, 141-176 (1988).

[3] Eng A. H., Tanaka Y.: Structure of natural rubber. Trends in Polymer Science, 3, 493-513 (1993). 
[4] Vaysse L., Bonfils F., Sainte-Beuve J., Cartault M.: Natural rubber. in 'Polymer science: A comprehensive reference polymers for a sustainable environment and green energy' (eds: McGrath J. E., Hickner M. A., Höfer R.) Elsevier, Amsterdam, 281-293 (2012).

[5] Montes S., White J. L.: A comparative rheological investigation of natural and synthetic cis-1,4 polyisoprenes and their carbon black compounds. Rubber Chemistry and Technology, 55, 1354-1369 (1982).

DOI: $10.5254 / 1.3535934$

[6] Li S-D., Yu H-P., Peng Z., Li P-S.: Study on variation of structure and properties of natural rubber during accelerated storage. Journal of Applied Polymer Science, 70, 1779-1783 (1998).

DOI: 10.1002/(SICI)1097-4628(19981128)70:9<1779:: AID-APP16>3.0.CO;2-A

[7] Bonfils F., Flori A., Sainte Beuve J.: Relations between wallace plasticity and $M_{\mathrm{w}}$ for natural rubber. Journal of Applied Polymer Science, 74, 3078-3087 (1999).

DOI: 10.1002/(SICI)1097-4628(19991220)74:13<3078 $\because$ AID-APP10>3.0.CO;2-6

[8] Kim C., Morel M-H., Sainte Beuve J., Guilbert S., Bonfils F.: Better characterization of raw natural rubber by decreasing the rotor speed of Mooney viscometer: Role of macromolecular structure. Polymer Engineering and Science, 50, 240-248 (2010).

DOI: $10.1002 /$ pen. 21525

[9] Campbell D. S., Fuller K. N. G.: Factors influencing the mechanical behavior of raw unfilled natural rubber. Rubber Chemistry and Technology, 57, 104-117 (1984). DOI: $10.5254 / 1.3535987$

[10] Ehabé E. E., Bonfils F., Aymard C., Akinlabi A. K., Sainte-Beuve J.: Modelling of Mooney viscosity relaxation in natural rubber. Polymer Testing, 24, 620-627 (2005).

DOI: $10.1016 /$ j.polymertesting.2005.03.006

[11] Subramaniam A.: Characterisation of natural rubber. in 'Proceeding of the international rubber technology conference. Kuala Lumpur, Malaysia' 19-36 (1993).

[12] Bonfils F., Doumbia A., Char C., Sainte-Beuve J.: Evolution in the natural rubber native structure and plasticity retention index from the first tapping of clonal trees. Journal of Applied Polymer Science, 97, 903-909 (2005). DOI: $10.1002 / a p p .21845$

[13] Voznyakovskii A. P., Dmitrieva I. P., Klyubin V. V., Tumanova S. A.: A dynamic light scattering study of natural rubber in solution. Polymer science Series A: Chemistry, Physics, 38, 1153-1157 (1996).

[14] Rippel M. M., Leite C. A. P., Lee L-T., Galemberg F.: Direct imaging and elemental mapping of microgels in natural rubber particles. Colloid and Polymer Science, 283, 570-574 (2005).

DOI: $10.1007 / \mathrm{s} 00396-004-1187-\mathrm{z}$
[15] Salomez M., Subileau M., Intapun J., Bonfils F., SainteBeuve J., Vaysse L., Dubreucq E.: Micro-organisms in latex and natural rubber coagula of Hevea brasiliensis and their impact on rubber composition, structure and properties. Journal of Applied Microbiology, 117, 921-929 (2014).

DOI: $10.1111 /$ jam.12556

[16] Liengprayoon S., Chaiyut J., Sriroth K., Bonfils F., Sainte-Beuve J., Dubreucq E., Vaysse L.: Lipid compositions of latex and sheet rubber from Hevea brasiliensis depend on clonal origin. European Journal of Lipid Science and Technology, 115, 1021-1031 (2013). DOI: $10.1002 /$ jlt.201300023

[17] Rolere S., Liengprayoon S., Vaysse L., Sainte-Beuve J., Bonfils F.: Investigating natural rubber composition with Fourier transform infrared (FT-IR) spectroscopy: A rapid and non-destructive method to determine both protein and lipid contents simultaneously. Polymer Testing, 43, 83-93 (2015).

DOI: 10.1016/j.polymertesting.2015.02.011

[18] Sansatsadeekul J., Sakdapipanich J., Rojruthai P.: Characterization of associated proteins and phospholipids in natural rubber latex. Journal of Bioscience and Bioengineering, 111, 628-634 (2011).

DOI: $10.1016 /$ j.jbiosc.2011.01.013

[19] Nawamawat K., Sakdapipanich J. T., Ho C. C.: Effect of deproteinized methods on the proteins and properties of natural rubber latex during storage. Macromolecular Symposia, 288, 95-103 (2010).

DOI: $10.1002 /$ masy.201050212

[20] Tarachiwin L., Sakdapipanich J. T., Tanaka Y.: Gel formation in natural rubber latex: 2. Effect of magnesium ion. Rubber Chemistry and Technology, 76, 1185-1193 (2003).

DOI: $10.5254 / 1.3547796$

[21] Tanaka Y., Tarachiwin L.: Recent advances in structural characterization of natural rubber. Rubber Chemistry and Technology, 82, 283-314 (2009). DOI: $10.5254 / 1.3548250$

[22] Tarachiwin L., Tanaka Y., Sakdapipanich J.: Structure and origin of long-chain branching and gel in natural rubber. Kautschuk Gummi Kunststoffe, 58, 115-122 (2005).

[23] Allen P. W., Bristow G. M.: The gel phase in natural rubber. Journal of Applied Polymer Science, 7, 603-615 (1963).

DOI: 10.1002/app.1963.070070217

[24] Kim C., Morel M-H., Sainte Beuve J., Guilbert S., Collet A., Bonfils F.: Characterization of natural rubber using size-exclusion chromatography with online multiangle light scattering: Study of the phenomenon behind the abnormal elution profile. Journal of Chromatography A, 1213, 181-188 (2008). DOI: $10.1016 /$ j.chroma.2008.10.052 
[25] Shiibashi T.: Gel structure characterization of NR and IR and direct observation of individual polymer molecules by electron microscopy. International Polymer Science and Technology, 14, T/33-T/39 (1987).

[26] Wisunthorn S., Liengprayoon S., Vaysse L., Sainte Beuve J., Bonfils F.: SEC-MALS study of dynamic structuring of natural rubber: Comparative study of two Hevea brasiliensis genotypes. Journal of Applied Polymer Science, 124, 1570-1577 (2012).

DOI: 10.1002/app.35099

[27] McMahan C., Kostyal D., Lhamo D., Cornish K.: Protein influences on guayule and Hevea natural rubber sol and gel. Journal of Applied Polymer Science, 132, 42051/1-42051/7 (2015)

DOI: 10.1002/app.42051

[28] Lu F. J., Hsu S. L.: A vibrational spectroscopic analysis of the structure of natural rubber. Rubber Chemistry and Technology, 60, 647-658 (1987).

DOI: $10.5254 / 1.3536148$

[29] Gregg E. C., Macey J. H.: The relationship of properties of synthetic poly(isoprene) and natural rubber in the factory. The effect of non-rubber constituents of natural rubber. Rubber Chemistry and Technology, 46, 4766 (1973).

DOI: $10.5254 / 1.3545022$

[30] Rolere S., Char C., Taulemesse J. M., Bergeret A., Sainte-Beuve J., Bonfils F.: The majority of minerals present in natural rubber are associated with the macrogel: An ICP-MS and SEM/EDX investigation. Journal of Applied Polymer Science, 133, 43062/1-43062/11 (2016).

DOI: 10.1002/APP.43062

[31] Yip E.: Clonal characterization of latex and rubber properties. Journal of Natural Rubber Research, 5, 5280 (1990).
[32] Yunyongwattanakorn J., Sakdapipanich J. T.: Physical property changes in commercial natural rubbers during long term storage. Rubber Chemistry and Technology, 79, 72-81 (2006). DOI: $10.5254 / 1.3547930$

[33] Varghese L., Geethakumari M. L., Thomas K. T., Mathew N. M.: Effect of storage on properties of marketable forms of natural rubber: Influence of humidity and temperature. Rubber India, 60, 39-46 (2008).

[34] Tangpakdee J., Tanaka Y.: Characterization of sol and gel in Hevea natural rubber. Rubber Chemistry and Technolology, 70, 707-713 (1997). DOI: $10.5254 / 1.3538454$

[35] Liengprayoon S., Bonfils F., Sainte-Beuve J., Sriroth K., Dubreucq E., Vaysse L.: Development of a new procedure for lipid extraction from Hevea brasiliensis natural rubber. European Journal of Lipid Science and Technology, 110, 563-569 (2008).

DOI: $10.1002 /$ jlt.200700287

[36] Flory P. J., Rehner J.: Statistical mechanics of crosslinked polymer networks II. Swelling. Journal of Chemical Physics, 11, 521-526 (1943). DOI: $10.1063 / 1.1723792$

[37] Intapun J., Sainte-Beuve J., Bonfils F., Tanrattanakul V., Dubreucq E., Vaysse L.: Effect of microorganisms during the initial coagulum maturation of Hevea natural rubber. Journal of Applied Polymer Science, 118, 13411348 (2010).

DOI: $10.1002 /$ app.32331

[38] Gan S-N., Ting K-F.: Effect of treating latex with some metal ions on storage hardening of natural rubber. Polymer, 34, 2142-2147 (1993). DOI: 10.1016/0032-3861(93)90742-S

[39] Bristow G. M., Watson W. F.: Cohesive energy densities of polymers. Part 2. - Cohesive energy densities from viscosity measurements. Transactions of the Faraday Society, 54, 1742-1747 (1958).

DOI: $10.1039 /$ TF9585401742 